\title{
ДОСЛІДЖЕННЯ МАКРО- ТА МІКРОЕЛЕМЕНТНОГО СКЛАДУ ЛИСТКІВ PINUS SYLVESTRIS L. TA PINUS MUGO TURRA
}

Вступ. Дослідження науковців, проведені в останні роки, показали, що існує певний зв'язок між вмістом у рослинах, лікарській рослинній сировині та харчових продуктах макро- і мікроелементів та частотою виникнення деяких захворювань. На здоров'я людини впливає цілий комплекс чинників, і вміст макро- та мікроелементів є лише одним із аспектів зазначеного зв'язку. Безпечна цінність біологічно активних речовин рослин полягає в тому, що вони містять у своєму складі збалансований комплекс елементів, які для організму людини не чужі. Багато лікарських рослин накопичують високу концентрацію необхідних для організму макро- та мікроелементів, що надає їм суттєвої переваги при проведенні профрілактики і лікування великої кількості захворювань, які пов'язані з порушенням балансу макро- та мікроелементів в організмі людини. Рослинна сировина здатна накопичувати хімічні елементи у процесі вегетації і виділяти ці сполуки при екстракції та отриманні комплексних орітопрепаратів.

Мета дослідження - дослідити макро- та мікроелементний склад листків сосни звичайної та сосни гірської, заготовлених в Україні, для вивчення можливості подальшого їх використання як фрітозасобів.

Методи дослідження. Дослідження проводили на базі Центру Біоелементології Івано-Франківського національного медичного університету. Визначали накопичення в досліджуваних видах таких елементів, як купрум, цинк, фрерум, кадмій, магній. Елементи визначали на атомно-абсорбційному спектрофротометрі C-115ПК у повітряно-ацетиленовому полум'ї з використанням комп'ютерного розшисрування їх вмісту порівняно зі стандартом.

Результати й обговорення. У листках сосни звичайної, заготовлених в Івано-Франківській області, визначено кількісний вміст макро- та мікроелементів, а саме: $\mathrm{Cu}, \mathrm{Zn}, \mathrm{Fe}, \mathrm{Mg}$, Cd, S, Co, Ni, Pb, Cr. Bмicm Cd перебував у гранично допустимих межах.

Висновки. Уперше досліджено склад макро- та мікроелементів сировини Pinus sylvestris L. i Pinus mugo TURRA, яка зростала на території Івано-Франківської та Закарпатської областей, виявлено 5 елементів. Установлено, що вміст макро- та мікроелементів у листках сосни звичайної і сосни гірської відповідає таким закономірностям: $\mathrm{Cu}>\mathrm{Zn}>\mathrm{Fe}>\mathrm{Cd}>\mathrm{Mg}$.

КЛЮЧОВІ СЛОВА: макро- та мікроелементи; сировина; сосна звичайна; сосна гірська.

ВСТУП. Пошук нових біологічно активних речовин для створення лікарських засобів різної спрямованої дії, а також пошук рослин, що можуть бути додатковою лікарською сировиною до офріцинальних видів, - одне з актуальних завдань фрармації.

Основними джерелами надходження мінеральних компонентів в організм людини є рослини. Вивчення їх елементного вмісту необхідне для більш повної характеристики розподілу хімічних елементів, оскільки рослини - важлива ланка біологічного кругообігу речовин [1].

Макро- та мікроелементи належать до речовин, які абсолютно необхідні для нормального фрункціонування організму людини. Вони беруть активну участь у складних біохімічних та фрізіологічних процесах, що забезпечують підтримання (с) Т. П. Мандзій, 2020. гомеостазу організму. Багато мікроелементів виконують певну фуннкцію в організмі та $€$ необхідними для деяких чітко визначених процесів.

Десріцит чи надлишок хімічних елементів впливає на всі ланки харчових ланцюгів, призводить до нестачі або надлишку їх в організмі, зміни характеру декодування, послаблення чи посилення синтезу біологічно активних речовин, що містять мікроелементи, перебудови процесів проміжного обміну речовин, нової адаптивної злагодженості або диссрункцій, що викликають захворювання людини [2].

Особливо велике значення для організму мають мікроелементи купрум (Cu), цинк (Zn), срерум (Fe), кадмій (Cd), магній (Mg). Їх роль в обміні речовин організму людини дуже важлива [3].

Макро- та мікроелементи відіграють важливу роль у підтримці організму людини, зумовлюють 
вплив на процеси кровотворення, тканинного дихання, імунні реакції, поділ клітин, ріст, розмноження, фрункцію залоз внутрішньої секреції.

Особливу увагу приділяють мінеральним сполукам, що є в лікарській рослинній сировині, в яких макро- і мікроелементи нагромаджуються у вигляді комплексів у найсприятливішому співвідношенні основних компонентів, у найбільш засвоюваній та доступній для організму людини формі. Рослинні організми як живі системи характеризуються відповідним ступенем нагромадження макро- і мікроелементів, що як фрактори зовнішнього середовища відіграють роль базисних модуляторів для синтезу органічних молекулярних структур та біологічно активних речовин іводночас дають можливість прослідкувати міграцію хімічних елементів у біосорері, з'ясувати механізми їх концентрування і визначити топографрію найбільш сприятливих, з екологічної точки зору, місць заготівлі сировини [4-10].

Магній належить до внутрішньоклітинних макроелементів. Він бере участь у метаболічних процесах, є активатором для багатьох ферментативних систем. Магній необхідний насамперед для забезпечення енергетичних процесів, а також регуляції синтезу і гідролізу АТФ, нервовом'язової провідності, підтримання тонусу гладеньких м'язів. Він стимулює синтез протеїнів, нуклеїнових кислот, відомий як антистресовий елемент. Магній має антиаритмічну дію, зміцнює імунну систему, є фрізіологічним антагоністом кальцію, контролює баланс внутрішньоклітинного калію. Цей макроелемент відіграє важливу роль у пригніченні агрегації тромбоцитів, проявляє гіпотензивну дію. Більша частина магнію надходить в організм з рослинною їжею [11].

Гіпермагніємію спостерігають при хронічній і гострій нирковій недостатності, хворобі Іценка Кушинга, атеросклерозі, гіпотиреозі. Гіпомагніємія характерна для стеатореї, діареї, первинного гіперальдостеронізму, гіпертиреозу, цирозу печінки.

В організмі дорослої людини міститься приблизно 3-5 г фреруму, більше половини його входить до складу гемоглобіну. Одна з важливих функцій фреруму полягає в транспорті кисню та участі в окиснювальних процесах, оскільки він $є$ важливим компонентом цитохромів, міоглобіну. Ферум відіграє важливу роль у процесах обміну холестеролу, енергетичного обміну, забезпечення імунних реакцій. Насичення клітин і тканин фрерумом відбувається завдяки протеїну трансорерину, який здатний транспортувати іони трьохвалентного феруму. В іонізованому стані ферум може виступати активатором вільнорадикальних процесів, що супроводжується накопиченням активних фрорм кисню [11].
Вміст фреруму в крові підвищується при внутрішньосудинному гемолізі, гемолітичній і перніціозній анемії, цирозах, гострих і хронічних гепатитах, усіх видах жовтяниць, десріциті вітаміну $\mathrm{B}_{12}$, знижується - при хронічних тривалих інсрекціях, інтоксикаціях, новоутвореннях [12].

Цинк належить до мікроелементів, є важливим кофрактором для ензимів, що забезпечують процеси синтезу нуклеїнових кислот і протеїнів, зокрема колагену, та фрормування кісткової тканини. Він бере участь у процесах поділу i диоеренціювання клітин, формуванні Т-клітинного імунітету, фрункціонуванні інсуліну й антиоксидантних ензимів, має важливе значення для процесів регенерації шкіри, росту волосся і нігтів. Цинк сприяє всмоктуванню і підтримці нормального рівня вітаміну E [13].

Важлива роль в обміні купруму в організмі людини належить церулоплазміну, який виконує антиоксидантну фрункцію. Він $є$ активатором багатьох гормонів і ензимів, зокрема гідроксидаз, які забезпечують посттрансляційні модифрікації колагену, що має важливе значення для сполучної тканини, кісток, стінок кровоносних судин, шкіри. Окрім того, купрум впливає на метаболізм еластину, входить до мієлінових оболонок нервових нервів. В обміні вуглеводів він активує процеси гліколізу та гальмує розпад глікогену. Антиоксидантна фрункція полягає і в активації супероксиддисмутази. Цей біоелемент підвищує стійкість організму до деяких інфекцій, має виражену протизапальну дію [11-13].

Гіперкупремія характерна для лейкозів, лімфогранулематозу, туберкульозу легень, ревматизму, гострого інфаркту міокарда, новоутворень, подагри. Гіпокупремію спостерігають при хворобі Коновалова - Вільсона, хронічній ішемічній хворобі серця, гастроентеритах, гестозах вагітних.

Кадмій належить до токсичних елементів, він характеризується високою міграційною швидкістю, біохімічною активністю, має політропну токсичну дію, тривалий період напіввиведення $з$ організму, що досягає 25-30 років, здатний кумулюватись в органах і тканинах. Він володіє високим ступенем депонування в печінці, нирках, кістковій тканині, що зумовлюєпорушення їх структури та фрункцій. Особливості біоцидних есректів іонів кадмію зумовлені їх антагонізмом з такими есенціальними мікроелементами, як цинк, кальцій, селен, мідь, залізо, та змінюють їх метаболізм [14-17].

Мета дослідження - дослідити макро- та мікроелементний склад листків сосни звичайної та сосни гірської, заготовлених в Україні, для вивчення можливостіподальшогоїхвикористання як фрітозасобів. 
МЕТОДИ ДОСЛІДЖЕННЯ. Дослідження проводили на базі Центру Біоелементології ІваноФранківського національного медичного університету. Листки сосни звичайної та сосни гірської заготовляли на території Івано-Франківської і Закарпатської областей. Визначали накопичення в досліджуваних видах таких елементів, як купрум, цинк, фрерум, кадмій, магній.

Елементи визначали на атомно-абсорбційному спектрофотометрі С-115ПК у повітряноацетиленовому полум'ї з використанням комп'ютерного розшифррування їх вмісту порівняно зі стандартом. При цьому тиск становив 0,4 кг/см² і 20 мм вод. ст. відповідно; температура полум'я $2250{ }^{\circ} \mathrm{C}$. Калібрувальні грасіки в інтервалі вимірюваних концентрацій елементів будували за допомогою стандартних проб розчинів солей металів (ICOPM-23-27). Для розчинення купруму використовували кислоту азотну особливої чистоти, а при аналізі інших елементів - реактиви кваліфрікації х.ч. та двічі очищену воду $[15,16]$.

РЕЗУЛЬТАТИЙ ОБГОВОРЕННЯ. РезУЛЬТаТИ дослідження елементного складу листків сосни звичайної та сосни гірської наведено в таблиці.

У листках сосни звичайної, заготовлених в Івано-Франківській області (2012р.), визначено кількісний вміст макро- та мікроелементів: $\mathrm{Cu}-$ 0,1864 мг/100 г; Zn - 0,5660 мг/100 г; Cd 0,0011 мг/100 г; S - 95,0 мг/100 г; Со $0,0029 \mathrm{mr} / 100$ г; $\mathrm{Ni}-0,2880 \mathrm{mг} / 100$ г; $\mathrm{Pb}-$ $0,0562 \mathrm{mr} / 100$ г; $\mathrm{Cr}-0,2950 \mathrm{мг} / 100$ г.

Таблиця - Кількісний вміст макро- і мікроелементів у листках сосни звичайної та сосни гірської

\begin{tabular}{|c|c|c|c|c|c|c|c|}
\hline \multirow{2}{*}{ Рослина } & \multirow{2}{*}{\multicolumn{2}{|c|}{ Місце і рік заготівлі }} & \multicolumn{5}{|c|}{ Вміст елементів, $\bar{x} \pm \Delta \bar{x}(n=6)$} \\
\hline & & & \multirow{2}{*}{$\begin{array}{c}\mathrm{Cu}^{*} \\
0,380 \pm \\
0,030\end{array}$} & \multirow{2}{*}{$\begin{array}{c}\mathrm{Zn*} \\
1,610 \pm \\
0,100\end{array}$} & \multirow{2}{*}{$\begin{array}{c}\mathrm{Fe}^{\star} \\
8,000 \pm \\
0,258\end{array}$} & \multirow{2}{*}{\begin{tabular}{c|}
$C d^{\star \star}$ \\
$0,250 \pm$ \\
0,033
\end{tabular}} & \multirow{2}{*}{$\begin{array}{c}\mathrm{Mg}^{*} \\
2,200 \pm \\
0,215\end{array}$} \\
\hline \multirow[t]{6}{*}{$\begin{array}{l}\text { Сосна } \\
\text { звичайна }\end{array}$} & \multirow{5}{*}{$\begin{array}{l}\text { Івано- } \\
\text { Франківська } \\
\text { область }\end{array}$} & $\begin{array}{l}\text { Надвірнянський район, околиці } \\
\text { м. Яремче, } 2013 \text { р. }\end{array}$ & & & & & \\
\hline & & $\begin{array}{l}\text { Тисменецький район, с. Угринів, } \\
\text { Дендрологічний парк “Дружба” } \\
\text { ім. Зіновія Павлика Прикарпат- } \\
\text { ського національного університету } \\
\text { ім. Василя Стесраника, } 2012 \text { р. }\end{array}$ & $\begin{array}{c}0,660 \pm \\
0,024\end{array}$ & $\begin{array}{c}1,820 \pm \\
0,128\end{array}$ & $\begin{array}{c}8,050 \pm \\
0,156\end{array}$ & $\begin{array}{c}0,350 \pm \\
0,020\end{array}$ & $\begin{array}{c}2,960 \pm \\
0,153\end{array}$ \\
\hline & & $\begin{array}{l}\text { Калуський район, м. Калуш, } \\
2013 \text { р. }\end{array}$ & $\begin{array}{c}0,680 \pm \\
0,019\end{array}$ & $\begin{array}{c}1,880 \pm \\
0,117\end{array}$ & $\begin{array}{c}8,880 \pm \\
0,203\end{array}$ & $\begin{array}{c}0,320 \pm \\
0,032\end{array}$ & $\begin{array}{c}4,200 \pm \\
0,080\end{array}$ \\
\hline & & $\begin{array}{l}\text { Надвірнянський район, } \\
\text { с. Микуличин, } 2011 \text { р. }\end{array}$ & $\begin{array}{c}0,530 \pm \\
0,044\end{array}$ & $\begin{array}{c}5,700 \pm \\
0,203\end{array}$ & $\begin{array}{c}9,460 \pm \\
0,203\end{array}$ & $\begin{array}{c}0,360 \pm \\
0,038\end{array}$ & $\begin{array}{c}4,100 \pm \\
0,148\end{array}$ \\
\hline & & $\begin{array}{l}\text { Калуський район, смт Войнилів, } \\
2013 \text { р. }\end{array}$ & $\begin{array}{c}0,410 \pm \\
0,023\end{array}$ & $\begin{array}{c}5,200 \pm \\
0,101\end{array}$ & $\begin{array}{c}9,420 \pm \\
0,178\end{array}$ & $\begin{array}{c}0,420 \pm \\
0,009\end{array}$ & $\begin{array}{c}3,900 \pm \\
0,143\end{array}$ \\
\hline & $\begin{array}{l}\text { Закарпатська } \\
\text { область }\end{array}$ & $\begin{array}{l}\text { Тячівський район, с. Солотвино, } \\
2012 \text { р. }\end{array}$ & $\begin{array}{c}0,390 \pm \\
0,024\end{array}$ & $\begin{array}{c}5,440 \pm \\
0,235\end{array}$ & $\begin{array}{c}15,100 \pm \\
0,336\end{array}$ & $\begin{array}{c}0,390 \pm \\
0,010\end{array}$ & $\begin{array}{c}4,900 \pm \\
0,321\end{array}$ \\
\hline \multirow[t]{4}{*}{$\begin{array}{l}\text { Сосна } \\
\text { гірська }\end{array}$} & \multirow{4}{*}{$\begin{array}{l}\text { Івано- } \\
\text { Франківська } \\
\text { область }\end{array}$} & $\begin{array}{l}\text { Надвірнянський район, околиці } \\
\text { м. Яремче, } 2010 \text { р. }\end{array}$ & $\begin{array}{c}0,670 \pm \\
0,022\end{array}$ & $\begin{array}{c}5,100 \pm \\
0,160\end{array}$ & $\begin{array}{c}10,650 \pm \\
0,378\end{array}$ & $\begin{array}{c}0,380 \pm \\
0,017\end{array}$ & $\begin{array}{c}4,800 \pm \\
0,203\end{array}$ \\
\hline & & $\begin{array}{l}\text { Надвірнянський район, } \\
\text { с. Микуличин, } 2010 \text { р. }\end{array}$ & $\begin{array}{c}0,630 \pm \\
0,025\end{array}$ & $\begin{array}{c}3,690 \pm \\
0,323\end{array}$ & $\begin{array}{c}14,800 \pm \\
0,336\end{array}$ & $\begin{array}{c}0,360 \pm \\
0,016\end{array}$ & $\begin{array}{c}3,740 \pm \\
0,207\end{array}$ \\
\hline & & $\begin{array}{l}\text { Тисменецький район, с. Угринів, } \\
\text { Дендрологічний парк “Дружба” } \\
\text { ім. Зіновія Павлика Прикарпат- } \\
\text { ського національного університету } \\
\text { ім. Василя Стесраника, } 2015 \text { р. }\end{array}$ & $\begin{array}{c}0,650 \pm \\
0,014\end{array}$ & $\begin{array}{c}2,360 \pm \\
0,153\end{array}$ & $\begin{array}{c}12,750 \pm \\
0,293\end{array}$ & $\begin{array}{c}0,400 \pm \\
0,012\end{array}$ & $\begin{array}{c}3,990 \pm \\
0,142\end{array}$ \\
\hline & & $\begin{array}{l}\text { Надвірнянський район, } \\
\text { с. Микуличин, } 2010 \text { р. }\end{array}$ & $\begin{array}{c}0,580 \pm \\
0,051\end{array}$ & $\begin{array}{c}3,640 \pm \\
0,317\end{array}$ & $\begin{array}{c}14,930 \pm \\
0,410\end{array}$ & $\begin{array}{c}0,370 \pm \\
0,017\end{array}$ & $\begin{array}{c}4,850 \pm \\
0,235\end{array}$ \\
\hline
\end{tabular}

Примітка. * - кількісний вміст елементів $\mathrm{Cu}, \mathrm{Zn}$, Fe та Mg розраховували в мг/кг сировини; ** - кількісний вміст елемента $\mathrm{Cd}$ розраховували в мкг/кг сировини.

У листках сосни звичайної та сосни гірської вміст Си становив 0,38-0,68 мг/кг сировини, $\mathrm{Zn}-1,61-5,70$ мг/кг сировини, Fe - 8,0015,10 мг/кг сировини, $\mathrm{Mg}-2,20-4,90 \mathrm{мг/кг}$ сировини. Максимальним вміст макро- і мікроелементів був у листках сосни звичайної: $\mathrm{Cu}-$
0,68 мг/кг сировини (Калуський район, м. Калуш, 2013 р.); Zn-5,7 мг/кг сировини (Надвірнянський район, с. Микуличин, 2010 р.); $\mathrm{Fe} \mathrm{i} \mathrm{Mg} \mathrm{-} \mathrm{15,10} \mathrm{i}$ 4,90 мг/кг сировини відповідно (Тячівський район, с. Солотвино, 2012 р.). Вміст Cd перебував у гранично допустимих межах. 
ВИСНОВКИ. Уперше досліджено склад макро- та мікроелементів сировини Pinus sylvestris L. i Pinus mugo TURRA, яка зростала на території Івано-Франківської та Закарпатської областей, виявлено 5 елементів. Установлено, що вміст макро- та мікроелементів у листках сосни звичайної та сосни гірської відповідає таким закономірностям: $\mathrm{Cu}>\mathrm{Zn}>\mathrm{Fe}>\mathrm{Cd}>\mathrm{Mg}$.

\section{СПИСОК ЛІТЕРАТУРИ}

1. Дослідження макро- та мікроелементів складу сировини Geum urbanum L. / С. А. Козира, М. А. Кулагіна, О. В. Рудько, А. Г. Сербін // Актуальні питання фрармац. і мед. науки та практики. - 2011. - № 3. C. $36-37$.

2. Калініченко О. А. Декоративна дендрологія : навч. посіб. / О. А. Калініченко. - К. : Вища школа, 2003. - 199 c.

3. Громадин А. В. Дендрология : учебник / А. В. Громадин, Д. Л. Матюхин. - М. : Издательский центр "Академия", 2006. - 360 с.

4. Сидора Н. В. Дослідження елементного складу плодів та екстрактів видів глоду / Н. В. Сидора, А. М. Ковальова // Мед. хімія. - 2007. - 9, № 1. C. $49-51$

5. Рибак О. В. Мікроелементний склад рудбекії роздільнолистої та ехінацеї пурпурової / О. В. Рибак // Мед. хімія. - 2006. - 8, № 1. - С. 53-55.

6. Криворучко О. В. Макро- і мікроелементний склад листя кизилу / О. В. Криворучко // Мед. хімія. 2008. - 10, № 4. - С. 81-84.

7. Бурда Н. С. Вивчення елементного складу деяких видів амаранту / Н. С. Бурда, В.С.Кисличенко // Фітотерапія. - 2005. - № 1. - С. 52-57.

8. Мікроелементний, амінокислотний та полісахаридний склад листя евкаліпта / О. М. Кошовий, А. М. Комісаренко, А. М. Ковальова [та ін.] // Фітотерапія. - 2005. - № 3. - С. 59-62.

9. Лихацький П. Г. Вивчення елементного складу надземної частини конюшини лучної / П. Г. Лихацький // Медична хімія. - 2007. - 7, № 4. - С. 58-60.

10. Adriano D. C. Trace elements in terrestrial environments: Biogeochemistry, bioavailability, and risks of metals. $-2^{\text {nd }}$ ed. - Springer-Verlag New York Inc. 2001. - P. 866.

11. Криворучко О. В. Макро- і мікроелементний склад листя кизилу / О. В. Криворучко // Мед. хімія. 2008. - 10, № 4. - С. 81-84.

12. Демидяк О.Л. Вивчення елементного складу суцвіття рослин роду Арніка / О. Л. Демидяк, І. В. Саска, С.М. Марчишин // Мед. хімія. - 2006. - 8, № 2. C. 121-123.

13. Елементний склад надземної частини ландшасту анісового та змієголовника молдавського / М. І. Шанайда, Л. С. Фіра, О. О. Вовчук [та ін.] // Мед. хімія. - 2005. - 7, № 2. - С. 62-65.

14. Сидора Н. В. Дослідження елементного складу плодів та екстрактів видів глоду / Н. В. Сидора, А. М. Ковальова // Мед. хімія. - 2007. - 9, № 1. C. $49-51$.

15. Державна Фармакопея України: в 3 т. / Державне підприємство "Український науковий фармакопейний центр якості лікарських засобів". - 2-ге вид. Харків : Державне підприємство "Український науковий фрармакопейний центр якості лікарських засобів", 2015. - 1. - 1128 c.

16. Мандзій Т. П. Фармакогностичне дослідження видів роду сосна : автореф. дис. на здобуття наук. ступеня канд. фрармац. наук / Т. П. Мандзій. - Запоріжжя : ЗДМУ, 2017. - 22 с.

17. Кричковська Л. В. Дослідження елементного складу в сосні звичайній / Л. В. Кричковська, С. В. Жирнова, Т. П. Мандзій // Химия, био- и нанотехнологии, экология и экономика в пищевой и косметической промышленности : тез. докл. II Междунар. науч.-практ. конф., 8-10 дек. 2014 г. - Харків, 2014. - С. 140-142.

\section{REFERENCES}

1. Kozyra, S.A., Kulahina, M.A., Rudko, O.V., \& Serbin, A.H. (2011). Doslidzhennia makro- ta mikroelementiv skladu syrovyny Geum urbanum L. [Composition of macro- and microelements Geum urbanum L.]. Aktualni pytannia farmatsevtychnoi i medychnoi nauky ta praktyky - Current Issues of Pharamaceutical and Medical Science and Practice, 3, 36-37 [in Ukrainian].

2. Kalinichenko, O.A. (2003). Dekoratyvna dendrolohiia: navch. posib. [Dendrology of plants: textbook]. Kyiv: Vyshcha shkola [in Ukrainian].
3. Gromadin, A.V., \& Matyukhin, D.L. (2006). Dendrologiya: uchebnik [Dendrology of plants; textbook]. Moscow: Izdatelskyy tsentr "Akademiya" [in Russian].

4. Sydora, N.V., \& Kovalova, A.M. (2007). Doslidzhennia elementnoho skladu plodiv ta ekstraktiv vydiv hlodu [Elemental composition of fruits and extracts of mayflower]. Medychna khimiia - Medical Chemistry, 9, 1, 49-51 [in Ukrainian].

5. Rybak, O.V. (2006). Mikroelementnyi sklad rudbekii rozdilnolystoi ta ekhinatsei purpurovoi [Trace 
element composition of green-headed coneflower and green-headed coneflower]. Medychna khimiia - Medical Chemistry, 8, 1, 53-55 [in Ukrainian].

6. Kryvoruchko, O.V. (2008). Makro-i mikroelementnyi sklad lystia kyzylu. [Macro and micronutrient composition of the dogwood leaves]. Medychna khimiia - Medical Chemistry, 10, 4, 81-84 [in Ukrainian].

7. Burda, N.S., \& Kyslychenko, V.S. (2005). Vyvchennia elementnoho skladu deiakykh vydiv amarantu [Study of element composition of some species of pigweed]. Fitoterapiia - Phytotherapy, 1, 52-57 [in Ukrainian].

8. Koshovyi, O.M., Komisarenko, A.M., \& Kovalova, A.M. (2005). Mikroelementnyi, aminokyslotnyi ta polisakharydnyi sklad lystia evkalipta [Microelement, aminoacid and polysaccharide composition of eucalyptus leaves]. Fitoterapiia - Phytotheray, 3, 59-62 [in Ukrainian].

9. Lykhatskyi, P.H. (2007). Vyvchennia elementnoho skladu nadzemnoi chastyny koniushyny luchnoi [Study of element composition of aboveground part of cow clower]. Medychna khimiia - Medical Chemistry, 7, 4, 58-60 [in Ukrainian].

10. Adriano, D.C. (2001). Trace elements in terrestrial environments: Biogeochemistry, bioavailability, and risks of metals. 2nd ed. Springer-Verlag New York Inc., 866 [in New York].

11. Kryvoruchko, O.V. (2008). Makro- i mikroelementnyi sklad lystia kyzylu [Macro- and microelement composition of dogwood leaves]. Medychna khimiia Medical Chemistry, 10, 4, 81-84 [in Ukrainian].

12. Demydiak, O.L., Saska, I.V., \& Marchyshyn, S.M. (2006). Vyvchennia elementnoho skladu sutsvittia roslyn rodu Arnika [Study of element composition of Arnica genus blossom]. Medychna khimiia - Medical Chemistry, 8, 2, 121-123 [in Ukrainian].
13. Shanaida, M.I., Fira, L.S., \& Vovchuk, O.O. (2005). Elementnyi sklad nadzemnoi chastyny landshaftu anisovoho ta zmiieholovnyka moldavskoho [Element composition of aboveground anise and Moldavian dragonhead visual environment]. Medychna khimiia Medical Chemistry, 7, 2, 62-65 [in Ukrainian].

14. Sydora, N.V., \& Kovalova, A.M. (2007). Doslidzhennia elementnoho skladu plodiv ta ekstraktiv vydiv hlodu [Elemental composition of fruits and extracts of mayflower]. Medychna khimiia - Medical Chemistry, 9, 1, 49-51 [in Ukrainian].

15. Derzhavna Farmakopeia Ukrainy: v 3 t. (2015). Derzhavne pidpryiemstvo "Ukrainskyi naukovyi farmakopeinyi tsentr yakosti likarskykh zasobiv", 2-e vyd. [State Pharmacopoeia of Ukraine: 3 vol./State Enterprise "Ukrainian Scientific Pharmacopoeial Center for Medicinal Products Quality"]. Derzhavne pidpryiemstvo “Ukrainskyi naukovyi farmakopeinyi tsentr yakosti likarskykh zasobiv" [in Ukrainian].

16. Mandzii, T.P. (2017). Farmakohnostychne doslidzhennia vydiv rodu sosna [Pharmacognostic study of pine species]. Candidate's thesis. Zaporizhzhia: ZDMU [in Ukrainian].

17. Krychkovska, L.V., Zhyrnova, S.V., \& Mandzii, T.P. (2014). Doslidzhennia elementnoho skladu v sosni zvychainii [Investigation of elemental composition in pine]. Tezy dopovidei Il Mezhdunarodnoy nauchno-prakticheskoy konferentsii "Khimiya, bio- i nanotekhnologii, ekologiya i ekonomika $v$ pyshchevoy $i$ kosmetycheskoy promyshlennosti - Chemistry, bio- and nanotechnology, ecology and economics in the food and cosmetic industry: II International Scientific and Practical Conference (December 8-10) [in Ukrainian].

\section{ИССЛЕДОВАНИЕ МАКРО- И МИКРОЭЛЕМЕНТНОГО СОСТАВА ЛИСТЬЕВ PINUS SYLVESTRIS L. И PINUS MUGO TURRA}

\section{Резюме}

Вступление. Исследования ученых, проведенные в последние годы, показали, что существует определенная связь между содержанием в растениях, лекарственном растительном сырье и пищевых продуктах макро- и микроэлементов и частотой возникновения некоторых заболеваний. На здоровье человека влияет целый комплекс фракторов, и содержание макро- и микроэлементов является лишь одним из аспектов указанной связи. Безопасная ценность биологически активных веществ растений заключается в том, что они содержат в своем составе сбалансированный комплекс элементов, которые для организма человека не чужие. Многие лекарственные растения накапливают высокую концентрацию необходимых для организма макро- и микроэлементов, что придает им существенного преимущества при проведении профилактики и лечения большого количества заболеваний, связанных с нарушением баланса макро- $и$ микроэлементов в организме человека. Растительное сырье способно накопливать химические элементы в процессе вегетации и выделять эти соединения при экстракции и получении комплексных фритопрепаратов.

Цель исследования - исследовать макро- и микроэлементный состав листьев сосны обыкновенной и сосны горной, заготовленных в Украине, для изучения возможности дальнейшего их использования в качестве фритопрепаратов. 
Методы исследования. Исследование проводили на базе Центра Биоэлементологии ИваноФранковского национального медицинского университета. В исследуемых видов определяли накопление таких элементов, как медь, цинк, железо, кадмий, магний. Элементы определяли на атомно-абсорбционном спектрофротометре C-115ПК в воздушно-ацетиленовом пламени с использованием компьютерной расшиорровки их содержания по сравнению со стандартом.

Результаты и обсуждение. В листьях сосны обыкновенной, заготовленных в Ивано-Франковской области, определено количественное содержание макро- и микроэлементов, а именно: $\mathrm{Cu}, \mathrm{Zn}, \mathrm{Fe}, \mathrm{Mg}, \mathrm{Cd}$, $\mathrm{S}, \mathrm{Co}, \mathrm{Ni}, \mathrm{Pb}, \mathrm{Cr}$. Содержание Cd находилось в предельно допустимых пределах.

Выводы. Впервые исследован состав макро- и микроэлементов сырья Pinus sylvestris L. u Pinus mugo TURRA, которое росло на территории Ивано-Франковской и Закарпатской областей, выявлено 5 элементов. Установлено, что содержание макро- и микроэлементов в листьях сосны обыкновенной и сосны горной соответствует таким закономерностям: $\mathrm{Cu}>\mathrm{Zn}>\mathrm{Fe}>\mathrm{Cd}>\mathrm{Mg}$.

КЛЮЧЕВЫЕ СЛОВА: макро- и микроэлементы; сырье; сосна обыкновенная; сосна горная.

\author{
T. P. Mandzii
}

IVANO-FRANKIVSK NATIONAL MEDICAL UNIVERSITY

\title{
THE STUDY OF MACRO- AND MICROELEMENT COMPOSITION OF LEAVES OF PINUS SYLVESTRIS L. AND PINUS MUGO TURRA
}

\section{Summary}

Introduction. Scientific studies in recent years have shown that there is a certain relationship between the content in plants, medicinal plant raw materials and food products of macro- and microelements and the incidence of certain diseases. Human health is influenced by a range of factors and the content of macro- and microelements is only one aspect of these connections. Safe value of biologically active substances (BAS) of plants is that they contain in its composition a balanced complex elements that for the human body are not strangers. Many medicinal plants can accumulate high concentrations of essential macro- and microelements, which gives them significant benefits in the prevention and treating large number of diseases associated with the imbalance of macro- and microelements in human organism. Plant material capable of accumulation of chemical elements in the process of vegetation and has the ability to the release of these compounds during extraction and formation of complex herbal remedies.

The aim of the study - to investigate the macro- and microelement composition of the leaves of pine and mountain pine harvested in Ukraine in order to study the possibility of their further use as phytopreparations.

Research Methods. The study was carried out on the basis of accredited Biochemical laboratory of IvanoFrankivsk National Medical University. In the studied species the accumulation of items such as cuprum, zinc, ferum, cadmium, magnesium was determined. Determination of elements was carried out on atomic absorption spectrophotometer C-115PC in the air-acetylene flame using computer decoding of the contents of elements in comparison with the standard.

Results and Discussion. The leaves of pine harvested in Ivano-Frankivsk region the quantitative content of macro- and microelements namely $\mathrm{Cu}, \mathrm{Zn}, \mathrm{Mg}, \mathrm{Cd}, \mathrm{S}, \mathrm{Co}, \mathrm{Ni}, \mathrm{Pb}, \mathrm{Cr}$. The content of $\mathrm{Cd}$ was within permissible limits.

Conclusions. For the first time there was studied the composition of macro- and micronutrients raw materials Pinus sylvestris L. and Pinus mugo TURRA which grew on the territory of Ivano-Frankivsk and Transcarpathian region 5 elements were identified. The content of macro- and microelements in the leaves of Pinus sylvestris $L$. and Pinus mugo TURRA correspond to the following patterns: $\mathrm{Cu}>\mathrm{Zn}>\mathrm{Fe}>\mathrm{Cd}>\mathrm{Mg}$.

KEY WORDS: macro- and micronutrients; raw materials; Pinus sylvestris; Pinus mugo.

Отримано 26.12.19

Адреса для листування: Т. П. Мандзій, вул. Хіміків, 21a/37, Івано-Франківськ, 76008, Україна, e-mail: tarasdgr@rambler.ru. 